\title{
SOPHOCLES, SEDUCTION AND SHRIVELLING: ICHNEUTAI FR. 316 RADT*
}

Sophocles fr. 316 comprises matching entries in Photius Lex. p.489 Porson and Suda $\rho 166$, which are thought to derive from Pausanias the Atticist's dictionary. ${ }^{1}$ Erbse presents the following text $(\rho 5):^{2}$

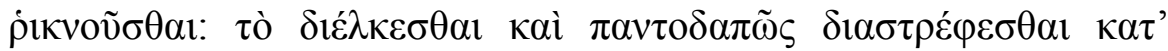

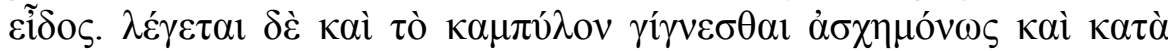

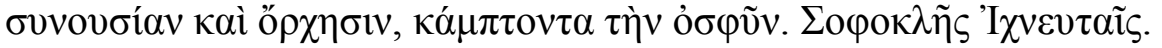

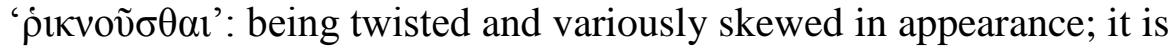
also used for lewdly making oneself curved, during sex or dancing, by curling the lower spine (Sophocles in the Ichneutai).

How the verb fitted in to the Ichneutai has gone unanswered. Radt ad loc. merely comments 'vix ad F 314.302 referendum'. ${ }^{3}$ I agree: the lexicographers cannot be trying to gloss that description, also from Ichneutai, of the tortoise from which Hermes has fashioned a lyre:

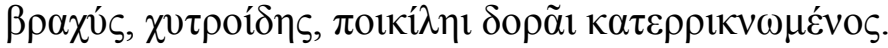

It is short, pot-shaped, and shrivelled up with a spotted skin.

Nevertheless, when the tragedians use a rare stem twice in the same play, the recurrence often forms an intratext to which one can attach some interpretative weight. Can one conjecture a significance-bearing reason why Sophocles might have used the extremely rare within the same play? ${ }^{4}$

I believe we can. The key is the remarkable 'coincidence' that the Homeric Hymn to Hermes - a text with much the same plot as Ichneutai and widely regarded as a source for Sophocles - also employs a phrase for 'to sway the lower spine sexily' 5

\footnotetext{
* My thanks to Lyndsay Coo and $C Q$ 's reader for advice, and to George Kazantzidis for interesting me in the uses of pikvós.

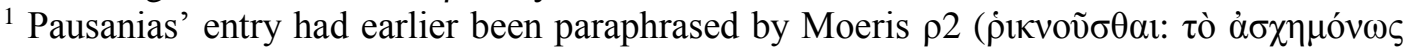

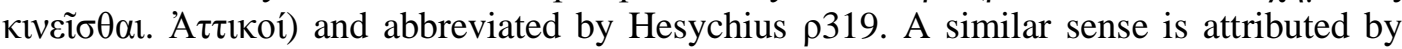

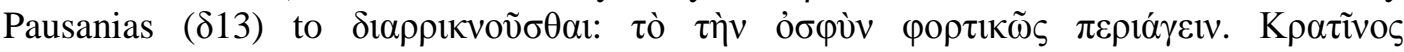

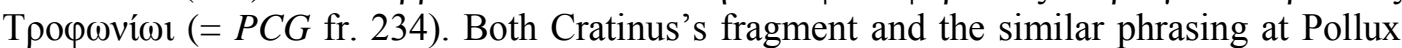
4.99 refer to dance. The only other non-lexicographical use of infinitive pıкvoṽ $\sigma \theta \alpha$ is Oppian Hal. 5.593, of the apparent shrivelling-up of marine molluscs with the waning moon.

${ }^{2}$ H. Erbse, Untersuchungen zu den Attizistischen Lexika (Berlin, 1950), 206.

${ }^{3}$ Similarly e.g. A.C. Pearson, The Fragments of Sophocles (Cambridge, 1917), 1.269; E.V. Maltese, Sofocle: Icheutai (Florence, 1982), 65.

4 Taking Gregory of Nyssa, who uses both verbs, as a cut-off, and excluding lexicographers, TLG finds seven uses of pıкvóouar and only Sophocles' use of

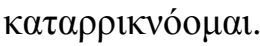

5 The relationship of H.Herm. and Ichn. is argued for by L. Koettgen, Quae ratio intercedat inter Indagatores fabulam Sophocleam et Hymnum in Mercurium qui fertur Homericus (Bonn 1914); Pearson (n.3), 1.225-8; J.A. Fernández Delgado, 'La lucha entre Hermes y Apolo del Epos al treatro: el Himno a Hermes como hipotexto de los Sabuesos de Sófocles', in J.V. Bañuls, F. de Martino and C. Morenilla (edd.), El teatro clásico en el
} 
As Hermes first leaves his cave the narrator, giving Hermes' focalisation,

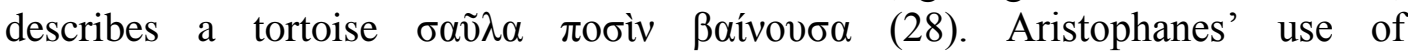

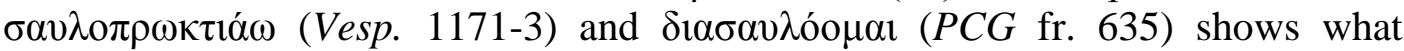
motion is intended - swaying the bottom from side to side, as tortoises indeed do as they walk. This swaying can imply vanity (as in e.g. Semonides $I E G^{2}$ fr. 18 and the Aristophanes passages), but also sensuality. The satyrs, according to Euripides Cyclops 39-40, once approached Althaea's house drunk, $\sigma \alpha v \lambda$ oú $\mu \varepsilon v o r$, and prepared to serenade her with a barbitos. Anacreon used the word similarly, according to Clement of Alexandria (Paed. 3.11.69):

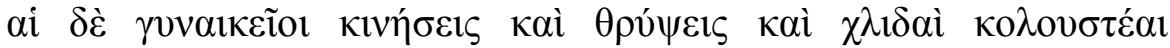

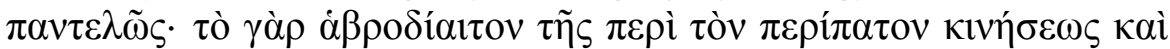

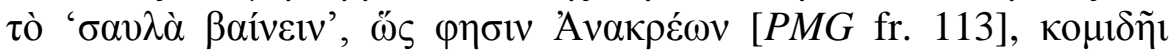

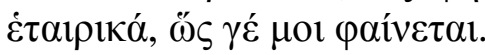

'Feminine movements and airs and luxuries must be completely curtailed: for pampered practices in one's gait and ' $\sigma \alpha \tilde{v} \lambda \alpha \beta \alpha i v \varepsilon v v$ ', in Anacreon's words, are utterly meretricious, in my humble opinion.'

That $\sigma \alpha \tilde{v} \lambda \alpha$ connotes sensuality in the Hymn to Hermes is confirmed just a few lines later, with Hermes' remarkable greeting (31):

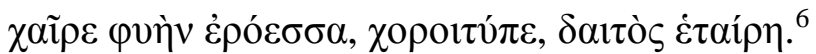

Be kindly, you gorgeous-bodied girl, who stamps in the chorus, who is a companion of the feast.

The Hymn to Hermes poses us a puzzle: how can Hermes see a sexy strut in the lumbering gait of a tortoise? This is not the place to discuss how that puzzle is gradually resolved. ${ }^{7}$ For our purposes, it is enough that the hymnist took an apparently unalluring specimen, and redescribed its walk in such terms.

Putting the lexicographers' entries together with $\sigma \alpha \tilde{v} \lambda \alpha \beta \alpha i v \varepsilon ı v$ in the Hymn to Hermes produces a plausible account of fr. 316 and its relationship to Ichn. 302.

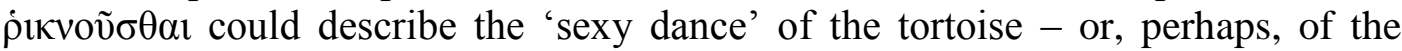
satyrs imitating a tortoise as they come to terms with its delightful music in the latter portion of the play. ${ }^{8}$ But the verb would also recall the preceding, accurate description of the tortoise as $\kappa \alpha \tau \varepsilon \rho \rho \iota \kappa \nu \omega \mu \varepsilon \dot{v o \varsigma}$ 'shrivelled'. This leaves us with an interesting new case of how satyr-plays pick up on and rework themes from epic, visible most obviously in Euripides' use of Odyssey 9 in his Cyclops. ${ }^{9}$ I submit that

marco de la cultura griega y su pervivencia en la cultura occidental (Bari, 2007), 113-56, at 121-55; A. Vergados, The Homeric Hymn to Hermes (Berlin, 2013), 79-86.

${ }^{6}$ Sophocles' only use of $\varphi v \eta$, in the discussion of the tortoise's form at Ichn. 307, may owe something to this very line.

${ }^{7}$ See my forthcoming 'Sparring Partners: Fraternal Relations in the Homeric Hymn to Hermes', in L-G. Canevaro, P. Bassino and B. Graziosi (edd.), Conflict and Consensus in Early Greek Hexameter Poetry.

${ }^{8}$ In 93-128 they imitate hunting-dogs. Possibly at 118-22, while describing the impossible prints of the cows, they try to clarify their report by enacting what the infer to have been the cows' stance. In any case, Silenus is astonished by their all-fours posture at 124 .

9 See most recently P. O'Sullivan and C. Collard, Euripides' Cyclops and Major Fragments of Greek Satyric Drama (Oxford, 2013). 
Accepted version: CQ 65 (2015), 364-5.

Sophocles not only took over the Hymn to Hermes' paradoxically sexy tortoise, but gave her a further 'twist in the tail', by encapsulating both sexiness and unsexiness intratextually into a single verb.

University of Nottingham

OLIVER THOMAS

oliver.thomas@nottingham.ac.uk 